\title{
Islamisasi Ilmu Pengetahuan (Konsep Pemikiran Ismail Raji Al-Faruqi dan Syed Muhammad Naquib Al-Attas)
}

\author{
SHOLEH \\ Fakultas Agama Islam (FAI) Universitas Islam Riau (UIR) Pekanbaru \\ Jl. Kaharuddin Nasution, No. 113, Perhentian Marpoyan Pekanbaru 28284 \\ Email: sholeh@yahoo.co.id
}

\begin{abstract}
Abstraksi: Fenomena terkait dengan pekembangan ilmu pengetahuan begitu pesat. Ditandai oleh munculnya ilmu-ilmu pengetahuan yang baru. Fenomena ini memunculkan sebuah dampak yang begitu besar bagi umat muslim. Sebab dengan perkembangan ilmu pengetahuan tersebut memicu suatu kebobrokan moral dan etika yang tidak berlandaskan agama Islam. Yang mana Islam telah diakui sebagai agama yang paling benar dan berakhlak. Dengan demikian muncullah sebuah kekritisan dari seorang cendekiawan muslim yang mencetuskan gagasan Islamisasi ilmu pengetahuan. Beliau adalah Ismail Raji Al-Faruqi dan Syed M. Naquib Al-Attas. Keduanya melihat fenomena perkembangan ilmu pengetahuan ini sudah melenceng dari ajaran-ajaran Islam. Sehingga membawa dampak seseorang menjadi sekuler. Berangkat dari sana kedua cendekiawan muslim ini melakukan Islamisasi pengetahuan dengan berbagai cara. Islamisasi ilmu pengetahuan merupakan langkah dalam menciptakan suatu peradaban Islam dalam dunia ilmu pengetahuan. Kedua tokoh besar tersebut menawarkan beberapa opsi dalam melakukan Islamisasi ilmu pengetahuan. Diantara opsi tersebut Syed M.Naquib Al-Attas menawarkan dua opsi dalam melakukan Islamisasi ilmu pengetahuan, yang pertama dengan melakukan pemisahan konsep-konsep kunci yang membentuk kebudayaan dan peradaban Barat. Yang kedua, dengan memasukan konsep kunci Islam ke dalam setiap cabang ilmu pengetahuan masa kini yang relevan. Dalam hal ini Ismail Raji Al-Faruqi juga menawarkan dua Konsep dalam melakukan Islamisasi ilmu pengetahuan. Yakni tauhid, integrasi kebenaran Islam dan ilmu pengetahuan, dan ayatisasi atau pemberian ayat-ayat terhadap ilmu pengetahuan.
\end{abstract}

Kata Kunci : Ilmu Pengetahuan, Ismail Raji Al-Faruqi, Syed M.Naquib Al-Attas

\section{PENDAHULUAN}

Pergulatan sebuah ilmu pengetahuan kini sangatlah terasa. Dimana pergulatan ini dirasakan ketika science mengalami perubahan yang begitu pesat dan diiringi oleh munculnya ilmu-ilmu baru. Seperti halnya ilmu psikologi, sosiologi dan ilmu-ilmu lainnya. Kehadiran ilmu-ilmu baru ini seakan-akan menunjukkan bahwa dunia ilmu pengetahuan berkembang begitu pesat. Dan dalam hal ini menunjukkan berkembangnya pemikiran-pemikiran para tokoh sehingga mampu memunculkan gagasan dan pemikirannya yang pada 
akhirnya mempunyai objek kajian tersendiri berupa ilmu pengetahuan.

Tidak sedikit klaim-klaim atas ilmu pengetahuan hingga sampai pada dewasa ini. seperti halnya klaim bahwa ilmu pengetahuan itu bebas nilai, ilmu pengetahuan itu hanya ilmu alam yang sifatnya pasti hingga sampai klaim yang mengatakan bahwa ilmu pengetahuan merupakan hasil dari peradaban barat. Yang notabenenya berangkat dari asumsi para tokoh dan pencetus ilmu pengetahuan tersebut berasal dari Barat. Hal ini seakan-akan mengklaim ilmu pengetahuan tersebut hanyalah milik dan muncul dari peradaban Barat.

Klaim-klaim tersebut membuat para orang timur atau tokoh sekaligus pemikir ilmu pengetahuan melihat ketidakadilan atas beberapa klaim ilmu pengetahuan yang seakan-akan mereduksi para tokoh-tokoh dunia Timur. Yang pada hakekatnya juga mempunyai peran penting dan merupakan sebagai pelaku sejarah dalam munculnya berbagai ilmu pengetahuan.

Contoh kongkritnya adalah AlJabar seorang cendekiawan muslim yang mencetuskan rumus Aljabar khususnya dalam ilmu matematika. Salah satu sumbangsi pemikiran yang penting dari pemikir orang timur sekaligus juga menjadi peradaban bagi orang-orang timur atas ilmu pengetahuan itu sendiri. Ada juga seorang filsuf ataupun tokoh sosiologi yang menawarkan konsep ashobiyah atau yang sering kita kenal dengan solidaritas sosial dalam menjawab berbagai persoalan Negara di zaman tersebut. Dalam hal ini idenya tertuang dalam suatu karya besar yang sampai sekarang masih digunakan referensi bagi kalangan sosiolog yakni bukunya yang berjudul "Mukaddimah". Dari pemikiran inilah yang mengilhami berbagai para tokoh dalam melihat ataupun menganalisis berbagai permasalahan-permasalahan masyarakat sehingga muncullah suatu disiplin ilmu mengenai masyarakat yakni Sosiologi. Dan masih banyak lagi berbagai pemikiran-pemikiran orangorang timur yang mempunyai sumbangsi begitu besar terhadap ilmu pengetahuan.

Berbagai sumbangsih yang diilhami oleh para pemikir orang timur ini menunjukkan bahwa harus ada klarifikasi dalam beberapa klaim diatas yang dilontarkan oleh stigma yang berkembang didunia mengenai peradaban ilmu pengetahuan yang selalu diarahkan pada dunia Barat.

Munculnya berbagai klaim mengenai ilmu pengetahuan berasal dari Barat dan menuai puncaknya di Barat, maka dengan demikian muncul pulalah berbagai perkembangan pemikiran kritis dari beberapa cendekiawan maupun intelektual muslim. Seperti halnya Ismail Raji AlFaruqi dan Syed Muhammad Naquib AlAttas yang mencetuskan dan mengembangkan konsep Islamisasi ilmu pengetahuan sebagai langkah kongkret baik dalam merekonstruksi maupun dekonstruksi beberapa klaim yang sudah di terstigma di dunia.

Maka dari itu pembahasan mengenai Islamisasi ilmu pengetahuan dirasa menarik untuk dikaji. Sebab Islamisasi ini lah yang diasumsikan sebagai perebut tonggak kejayaan yang pernah diraih oleh umat Islam ketika di Spanyol.

\section{KONSEP TEORI}

\section{Ilmu pengetahuan dan Dimensi Islam dalam Konsep Kebenaran}

Konsep imu pengetahuan dan dimensi Islam dalam melihat kebenaran ini sangat penting kita bahas terlebih dahulu. Sebab konsep ilmu pengetahuan dan dimensi Islam ini menjadi pondasi dasar bagi kita dalam 
melihat dan terjadinya Islamisasi ilmu pengetahuan. Terdapat dua konsep dalam menjawab pertanyaan ini yakni dengan menemukan apa konsep dari ilmu pengetahuan dan apa konsep Islam dalam melihat kebenaran.

Secara garis besar ketika melihat perkembangan ilmu pengetahuan ini seakan-akan menjadikan perkembangan ilmu pengetahuan ini semakin sekuler dari nilai-nilai agama khususnya agama Islam. Seakan-akan ada tembok raksasa yang menghalangi atau membatasi antara ilmu pengetahuan yang ada Barat dengan nilai-nilai Islam. Islam dikonsepsikan sebagai agama yang konservatif atau kolot. Dikarenakan Islam telah mengembalikannya secara normatif yakni pada kebenaran wahyu. Untuk lebih jelasnya akan kita bahas apa konsep atau sifat dari ilmu pengetahuan itu sendiri dan dimensi Islam itu sendiri dalam menilai kebenaran dan sumbangsih terhadap Islamisasi ilmu pengetahuan.

\section{Ilmu Pengetahuan}

Ilmu pengetahuan ini banyak diartikan para tokoh sebagai kumpulan dari pengetahuan-pengetahuan yang tersusun secara sistematis, bisa diukur, diuji dan diamati. Masuk dalam dunia ilmu pengetahuan maka berada dalam wilayah hitam dan putih. Dimana dalam ilmu pengetahuan kita berada dalam posisi benar atau salah. Benar atau salah ini merupakan kajian dari ilmu pengetahuan secara subtansinya.

Menilai benar atau salah bukanlah hal yang mudah. Sebab dalam ilmu pengetahuan ukuran benar dan salah ini akan diukur secara ilmiah yakni dengan kaidah-kaidah keilmiahan. Yang diantaranya bisa diukur, diuji dan diamati.

Diluar keilmiahan sebuah ilmu pengetahuan dapat dilihat juga dalam sudut pandang filsafat ilmu. Dimana filsafat ilmu ini juga menjadi tolak ukur bahwa apa yang dijadikan objek tersebut bisa dikatakan sebagai ilmu pengetahuan. Dalam kajian filsafat ilmu ada tiga hal yang menjadi dasar sebagai tolak ukur sebuah objek dikatakan sebagai ilmu pengetahuan. Pertama, Ontologi. Ontologi terdiri dari dua suku kata, yakni ontos dan logos. Ontos berarti sesuatu yang berwujud dan logos berarti ilmu. Jadi ontologi adalah bidang pokok filsafat yang mempersoalkan hakikat keberadaan segala sesuatu yang ada. Ontologi dapat pula diartikan sebagai ilmu atau teori tentang wujud hakikat yang ada. Obyek ilmu atau keilmuan itu adalah dunia empirik, dunia yang dapat dijangkau pancaindera. Dengan demikian, obyek ilmu adalah pengalaman inderawi. Dengan kata lain, ontologi adalah ilmu yang mempelajari tentang hakikat sesuatu yang berwujud dengan berdasarkan pada logika semata. Obyek telaah ontologi adalah yang ada. Berdasarkan hal tersebut, maka dapat dikatakan bahwa obyek formal dari ontologi adalah hakikat seluruh realitas. ontologi membahas apa yang ingin diketahui atau dengan kata lain merupakan suatu pengkajian mengenai teori tentang ada. (Jujun Sumantri, Filsafat Imu sebuah pengantar populer, Hal 34-35)

Kedua, Epistemologi. Kalau Ontologi membahas sesuatu yang ada. Namun epistemologis lebih membahas tentang terjadinya dan kebenarananya kebenaran ilmu. Epistemologi berasal dari bahasa Yunani episteme dan logos. Episteme berarti pengetahuan dan logos berarti ilmu. Dengan demikian epistemologi secara etimologis berarti ilmu pengetahuan. Epistemologi mengkaji mengenai apa sesungguhnya ilmu, dari mana sumber ilmu, serta bagaimana proses terjadinya. 
Epistemologi adalah pengetahuan sistematis yang membahas tentang terjadinya pengetahuan, sumber pengetahuan, asal mula pengetahuan, metode atau cara memperoleh pengetahuan, validitas dan kebenaran pengetahuan. Epistemologi bagian dari cabang atau bagian filsafat yang membicarakan tentang pengetahuan yaitu tentang terjadinnya pengetahuan dan kebenaran pengetahuan. Epistemologi lebih mengarah pada bagaimana mendapatkan pengetahuan, sumber-sumber pengetahuan, ruang lingkup pengetahuan.

Ketiga, Aksiologi. Aksiologi merupakan cabang filsafat ilmu yang mempertanyakan bagaimana manusia menggunakan ilmunya. (Burhanuddin Salam, Logika Materil, Filsafat Ilmu Pengetahuan.

Aksiologi adalah istilah yang berasal dari kata Yunani yaitu axios yang berarti sesuai atau wajar. Sedangkan logos yang berarti ilmu. Aksiologi dipahami sebagai teori nilai.

Aksiologi adalah ilmu yang membicarakan tentang tujuan ilmu pengetahuan itu sendiri. Jadi Aksiologi merupakan ilmu yang mempelajari hakikat dan manfaat yang sebenarnya dari pengetahuan, dan sebenarnya ilmu pengetahuan itu tidak ada yang sia-sia kalau kita bisa memanfaatkannya dan tentunya dimanfaatkan dengan sebaikbaiknya dan di jalan yang baik pula. Karena akhir-akhir ini banyak sekali yang mempunyai ilmu pengetahuan yang lebih itu dimanfaatkan di jalan yang tidak benar. Pembahasan aksiologi menyangkut masalah nilai kegunaan ilmu. Ilmu tidak bebas nilai.

Dalam ilmu pengetahuan aspek rasionalitas begitu dipertimbangkan, sebab ketika suatu pengetahuan tersebut tidak dapat diterima oleh otak atau yang sifatnya irrasional maka pengetahuan tersebut belum bisa dikatakan sebagai ilmu pengetahuan.
Namun tidak hanya cukup diolah oleh rasio manusia atau yang hanya masuk akal saja. Akan tetapi aspek empiris juga mempunyai andil yang begitu besar dalam syarat dikatakan sebagai ilmu pengetahuan.

Empiris disini diartikan sebagai pengalaman yang telah dilakukan dalam memperkuat pengetahuan yang telah diproses di rasio manusia. Empiris sangat menentukan bahwa ilmu pengetahuan ini telah diuji dan dapat dibenarkan ketika hasil uji yang dilaksanakan bisa diolah oleh rasio dan dibenarkan oleh rasio. Peran rasio dengan empiris begitu bersinggungan. Dimana hasil empiris tidak akan dibenarkan ketika tidak melalui hukumhukum logika yang terbentuk oleh rasio manusia. Begitu juga sebaliknya, pengetahuan yang rasional tanpa dilandasi sebuah empiris atau pengujian maka tidak menuntut kemungkinan pengetahuan tersebut menjadi pengetahuan irrasional. Yang mana pengetahuan irrasional inilah yang ditentang oleh ilmu pengetahuan.

Dalam ilmu pengetahuan tidak mengenal abu-abu. Atau wilayah ambiguitas. Dimana ilmu pengetahuan membicarakan mana yang hitam mana yang putih. Mana yang salah mana yang benar. Ilmu pengetahuan bersifat kongkret. Kongkrit disini diartikan sebagai suatu yang nampak dan terlepas dari transedental.

\section{Dimensi Islam Dalam Menilai Kebenaran}

Islam disini diartikan sebagai agama yang turun dari Allah SWT melalui malaikat Jibril kepada nabi Muhammad SAW. Datangnya Islam disambut dengan bahagia oleh sebagian ummat manusia. Dengan kedatangan Islam ummat manusia terlepas dari zaman jahiliyah atau yang kita kenal sebagai zaman kebodohan. Berhasilnya 
Islam mengentaskan umat manusia dari zaman kebodohan ini merupakan prestis bagi agama Islam itu sendiri.

Agama yang telah diturunkan pada nabi Muhammad SAW ini merupakan agama penyelamat. Dimana Islam yang berasal dari kata aslamah yang artinya keselamatan. Islam hadir sebagai penyempurna sekaligus penyelamat bagi umat manusia yang ada didunia ini.

Nilai keselamatan ini semuanya sudah diatur oleh Allah SWT dalam sebuah wahyunya. Wahyu merupakan hal yang mendasar sebagai pondasi dasar bagi kaum muslim untuk bertindak dan berpijak dalam melakukan sesuatu. Mulai fiqih, muamalah hingga sampai tauhid dan ilmu pengetahuan pun dibahas dan diatur oleh Allah SWT melalui wahyunya.

Wahyu dinilai sebagai kekuatan yang dianggap sakral oleh para pengikutnya. Dimana segala tingkah laku manusia haruslah sesuai dengan wahyu yang telah diturunkan. Wahyu mempunyai kekuatan penuh dalam mengatur kehidupan. Baik kehidupan di dunia maupun di akhirat.

Agama dalam hal ini khususnya Islam menganggap suatu kebenaran tersebut hanyalah milik Allah SWT. Sedangkan wujud atau substansi dari Allah SWT ini terletak pada Al-Qur'an dan Al-Hadits. Al-Qur'an dan Al-Hadits ini dianggap sebagai suatu yang sakral dalam agama Islam. Sebab segala sesuatu bagi kaum muslim yang menjadi rujukan adalah Al-Qur'an dan Hadits.

Nilai kebenarannya pun selalu terpusat pada nilai-nilai keyakinan yang dilalui melalui doktrin agama yang sehingga pada akhirnya menjadi dogma diantara pengikutnya. Dengan adanya dogma ini mengembalikan semua kebenaran hanya pada Al-Qur'an dan Al-Hadits.

Islam menilai suatu kebenaran dengan yang bernilai tauhid atau keEsaan Tuhan, kekuasaan tuhan dan semua kembali pada Tuhan yang maha Esa. Berdasarkan uraian diatas dapat kita simpulkan dikotomis wilayah ilmu pengetahuan dan dimensi Islam dalam tabel berikut :

\section{Tabel 1: Dikotomis Wilayah Ilmu Pengetahuan dan Dimensi Islam}

\section{Ilmu Pengetahuan Dimensi Islam}

1. Sumber kebenarannya berdasarkan rasio dan empiris

2. Kongkrit

3. Kebenarannya bersifat tentatif

4. Dualisme, hitam dan putih

5. Korespondensi, pragmatis dan koherensi sebagai metode pembenaran

6. Profan
1. Kebenaran besumber dari Tuhan Yang Kuasa.

2. Abstraksi/trasendental

3. Kebenarannya bersifat Dogma

4. Tauhid

5. Hati (keyakinan) diigunakan sebagai metode pembenaran atas penafsiran tentang sesuatu

6. Sakral
Tabel 1 diatas menunjukkan adanya kontradiksi dalam kedua kolom. Baik itu ilmu pengetahuan dan dimensi Islam. Dimana dalam ilmu pengetahuan kebenararan rasional dan empiris merupakan suatu kebenaran utama yang menjadi pondasi dasar pengetahuan itu dikatakan benar.

Dengan rasionalitas manusia mampu menemukan suatu 
kebenarannya melalui proses kerja otak. Kerja otak inilah yang menjadi salah satu penentu atau syarat dari ilmu pengetahuan. Berbeda halnya dengan dimensi Islam yang notabenenya melihat kebenaran semuanya berdasarkan Tuhan Yang Maha Esa.

Dalam hal ini kebenaran Tuhan adalah kebenaran mutlak yang harus dibenarkan baik secara rasionalitas maupun empiris melalui proses dogmatisasi atau keyakinan. Ketika kita lihat dalam tabel 1.1 ini juga menunjukkan adanya suatu ruang lingkup dalam kedua pandangan baik ilmu pengetahuan maupun dimensi Islam dalam melihat dan mengkaji objeknya. Pada ilmu pengetahuan menilai ruang lingkup kajiannya tidaklah di batasi oleh ruang-ruang sehingga menjauhkan diri dari sifat metanarasi pengetahuan. Sehingga beranggapan bahwa ilmu pengetahuan adalah free value atau bebas nilai dalam konteks ini ilmu pengetahuan dalam ruang lingkupnya bersifat profan yang dapat diartikan sebagai pembahasan yang terjadi intervensi normatif sehingga menimbulkan ilmu pengetahuan itu bersifat laden value atau syarat akan nilai-nilai.

Hal ini berbeda dengan dimensi Islam yang melihat ruang lingkup pengetahuan melalui proses yang dinamakan sebagai sakralitas pengetahuan. Dimana pengetahuan selalu dibenturkan oleh nilai-nilai sakralitas yang pada intinya bernilai atau sebagai wujud trasendental bagi manusia dan Tuhannya. Segala sesuatu dilaksanakan dan dikonsep untuk bagaimana proses trasendental ini tetap dilakukan oleh umat Islam dengan tidak meninggalkan suatu proses berkembangnya dunia yang terjadi. Dan dalam dimensi Islam menggunakan pendekatan dogma dalam menilai kebenaran-kebenaran. Yang mana dalam hal ini ilmu pengetahuan lebih melihat suatu kebenaran dengan beberapa metode yakni korespondensi, koherensi dan pragmatis.

Maraknya kajian dan integrasi keilmuan antara ilmu Islam dengan ilmu non Islam (Islamisasi ilmu pengetahuan) dewasa ini dengan senter didengungkan oleh kalangan intelektual muslim antara lain Naquib Al Attas dan Ismail Raji' Al Faruqi, tidak lepas dari kesadaran berIslam ditengah pergumulan dunia global yang sarat dengan kemajuan iptek. Ia misalnya berpendapat bahwa umat Islam akan maju dan dapat menyusul Barat manakala mampu mentransformasikan ilmu pengetahuan dalam memahami wahyu atau sebaliknya mampu memahami wahyu untuk mengembangkan ilmu pengetahuan.

Sehingga muncullah sebuah asumsi bahwa seakan-akan menciptakan sebuah perbedaan yang membedakan antara ilmu surga dan ilmu neraka. Dan juga membedakan ilmu yang barokah dengan ilmu yang berlumuran dosa. Diakui atau tidak Islamisasi ilmu pengetahuan ini telah lama diperbincangkan oleh kaum cendekiawan muslim yakni Ismail Raji Al-Faruqi dan Syed Naquib Al-Attas pada tahun bekisaran 1970an.

Kedua tokoh ini memang dikenal sebagai tokoh munculnya gagasan mengenai Islamisasi ilmu pengetahuan. Namun dibeberapa referensi buku menyebutkan bahwa tidak diketahui siapa yang pertama kali mencetuskan pertama kali gagasan mengenai Islamisasi ilmu pengetahuan. Namun diantara keduanya mempunyai cara pandang yang berbeda mengenai latar belakang munculnya gagasan Islamisasi ilmu pengetahuan. Ini juga dikarenakan di kedua tokoh tersebut dilahirkan dalam situasi geografi dan demografi yang berbeda. 


\section{Latar Belakang Adanya Konsep Islamisasi}

Salah satu alasan mendasar mengenai gagasan tentang Islamisasi ilmu pengetahuan dikarenakan tidak adanya landasan pengetahuan yang bersifat netral, sehingga ilmu pun tidak dapat berdiri bebas nilai. Ilmu Sosial sudah tidak lagi bebas nilai akan tetapi sifatnya syarat nilai. Pengetahuan dan ilmu yang ada didunia ini, termasuk dalam dunia Islam, telah diwarnai corak budaya dan peradaban Barat. Seakan ilmu pengetahuan bersumber dari otakotak orang Barat.

Al-Attas, salah seorang cendekiawan muslim, mengatakan bahwa pengetahuan Barat telah membawa pada keadaan yang anomi dan skeptis. Peradaban Barat melihat keadaan anomi dan skeptis ini sebagai suatu sarana epistimologis yang utama dalam menenukan sebuah kebenaran. Pada dasarnya Islam juga mempunyai kontribusi yang sangat penting pada peradaban Barat pada ranah pengetahuan dan menanam cara berfikir positifis, walaupun kita tahu bahwa ilmu pengetahuan banyak di lahirkan oleh pemikir Barat. Tepatnya para filosof mulai zaman Yunani Klasik hingga sampai yang modern. Namun diakui atau tidak, peran cendekiawan muslim sangatlah penting dalam intervensi dan pengaruh perkembangan ilmu pengetahuan yang digagas oleh para filosof Barat.

Bahkan,

pengetahuanpengetahuan telah diaplikasikan untuk kesejahteraan umat manusia, setelah dilakukan usaha-usaha secara ilmiah melalui penelitian dan percobaan. Barat mengambil alih pengetahuan dan ilmu tersebut dari dunia Islam. Pengetahuan dan semangat rasional serta semangat ilmiah tersebut dibentuk dan dikemas kembali untuk disesuaikan dengan kebudayaan Barat sehingga lebur dan terpadu dalam suatu dualisme menurut pandangan hidup dan nilai-nilai kebudayaan serta peradaban Barat. Menurut al-Attas, dualisme tidak mungkin diselaraskan karena terbentuk dari ide-ide, nilai-nilai, kebudayaan, keyakinan, filsafat, agama, doktrin, dan teologi yang bertentangan.

Nilai kebenaran dan realitas pada dunia Barat tidaklah mengacu pada kebenaran yang melalui proses keyakinan. Dalam hal ini ada dogma agama yang berupa isi kitab suci seperti halnya Al-Quran dan Hadist, melainkan menilai kebenaran tersebut melalui budaya yang berdasarkan atas pemikiran filsafat yang berupa spekulasi-spekulasi belaka.

Perenungan filsafat tidak akan menghasilkan suatu keyakinan sebagaimana Islam menilai suatu kebenaran juga melalui keyakinankeyakinan atas kebenaran tersebut. Oleh sebab itu pengetahuan dan nilainilai yang mendasari akan menjadikan pandangan hidup yang mengarahkan kepada kehidupan Barat.

Realitas dan kebenaran dalam Islam bukanlah semata-mata fikiran tentang dunia kosmos yang sifatnya fisik dan yang mengarahkan pada dunia sekuler. Akan tetapi realitas dan kebenaran dalam Islam dimaknai berdasarkan kajian metafisis terhadap dunia yang nampak dan tidak nampak.

Pandangan hidup Islam tidak berdasarkan kepada metode dikotomis seperti subjektif dan objektif, historis dan normatif. Namun, realitas dan kebenaran dalam Islam dengan metode yang menyatukan atau yang biasa kita kenal konsep tauhid. Pandangan hidup Islam bersumber kepada wahyu yang didukung oleh akal dan intuisi. Substansi agama seperti keimanan dan pengalamannya, ibadahnya, doktrinnya serta sistem teologinya telah ada dalam wahyu dan dijelaskan oleh Nabi. 
Hal ini menunjukkan bahwa terjadi paradigma atau cara pandang yang berbeda antara nilai-nilai Barat dengan nilai-nilai keIslaman. Karena Barat mendasarkan segala sesuatunya dengan kecenderungan pada dikotomisme atau dua pandangan yang berbeda. Sedangkan Islam pada konsep penyatuan atau tauhid. Dari situlah kemudian al-Attas mencoba untuk menggagas sebuah konsep Islamisasi yang diharapkan dari konsep ini akan menemukan dan meraih kembali peradaban Islam yang pernah diraih.

Salah seorang tokoh yang juga menjadi penggagas konsep Islamisasi pengetahuan sosial Ismail Raji AlFaruqi yang mengatakan bahwa umat Islam saat ini berada dalam keadaan yang lemah. Kaum muslim dianggapnya berada dalam kondisi degradasi baik dalam ilmu pengetahuan maupun lainnya. Dengan kondisi yang demikian ini menyebabkan kebodohan dikalangan kaum muslim itu sendiri.

Di kalangan kaum muslimin berkembang buta huruf, kebodohan, dan tahayul. Akibatnya, umat Islam lari kepada keyakinan yang buta, bersandar kepada literalisme dan legalisme, atau menyerahkan diri kepada pemimpinpemimpin atau tokoh-tokoh mereka. Meninggalkan dinamika ijtihad sebagai suatu sumber kreativitas yang semestinya dipertahankan. Zaman kemunduran umat Islam dalam berbagai bidang kehidupan telah menempatkan umat Islam berada di anak tangga bangsa-bangsa terbawah.

Dalam kondisi seperti ini, masyarakat muslim melihat kemajuan Barat sebagai sesuatu yang mengagumkan. Hal ini menyebabkan sebagian kaum muslimin tergoda oleh kemajuan Barat dan berupaya melakukan reformasi dengan jalan westernisasi. Ternyata jalan yang ditempuh melalui jalan westernisasi telah menghancurkan umat Islam sendiri dari ajaran Al-Qur'an dan Hadist. Sebab berbagai pandangan dari Barat, diterima umat Islam tanpa dibarengi dengan adanya filter dalam menyaring mana kebudayaaan dan ilmu pengetahuan yang bisa kita ambil sebagai sintesa kebenaran.

Hal ini menjadi problem tersendiri bagi kaum muslim. Dimana kaum muslim sudah terjebak pada dunia westernisasi. Yang ditandai oleh hidup keBarat-Baratan. Westernisasi tidak hanya pada rana pandangan hidup dalam keseharian mulai food, fun and fashion. Melainkan juga masuk pada rana ilmu pengetahuan. Dimana ilmu pengetahuan sudah terkonstuk dalam pemikiran-pemikiran Barat. Ini menjadikan pemikiran seseorang menjadi sekuler.

Banyak generasi muda muslim yang berpendidikan Barat bahkan telah memperkuat westernisasi dan sekulerisasi di lingkungan perguruan tinggi. Walaupun dalam aspek-aspek tertentu kemajuan Barat ikut memberi andil positif bagi umat, namun Ismail Raji Al-Faruqi mengatakan bahwa kemajuan yang dicapai umat Islam bukan sebagai kemajuan yang dikehendaki oleh ajaran agamanya.

Kemajuan yang dicapai, hanya merupakan kemajuan semu yang sifatnya masih ambigu. Karena disatu sisi umat Islam telah banyak mengadopsi hasil dari peradaban Barat. Akan tetapi disisi lain kaum muslim juga kehilangan pijakan yang bersumber pada pedoman hidup kaum muslim yakni kesakralan nilai-nilai moral agama.

Berangkat dari fenomena tersebut Ismail Raji Al-Faruqi melihat kenyataan bahwa umat Islam seakan berada di persimpangan jalan. Sulit untuk menentukan pilihan arah yang tepat. Karenanya, umat Islam akhirnya terkesan mengambil sikap mendua, antara tradisi keislaman dan nilai-nilai 
peradaban Barat. Pandangan dualisme yang demikian ini menjadi penyebab dari kemunduran yang dialami umat Islam.

Proses westernisasi pasca penjajahan Barat, terjadi di hampir seluruh negara muslim. Dan bisa dikatakan hal itu telah menghancurkan umat Islam dari ajaran al Qur'an dan Hadits. Dengan adanya westernisasi, berbagai pandangan hidup Barat diterima umat Islam tanpa adanya filter sebagai penyaring kehidupan Barat yang masuk di dunia Islam. Sehingga umat Islam dewasa ini menjadi kebingungan tanpa arah. Yang disebabkan oleh keadaan kultur integritas Islam terpecah baik dalam aspek pemikiran maupun perbuatan.

Berangkat dari hal tersebut, Ismail Raji Al-Faruqi berfikir bahwa salah satu cara dalam menghilangkan dualisme tersebut dengan cara mengislamisasikan pengetahuanpengetahuan atau dengan melakukan sebuah akulturasi sebuah pengetahuanpengetahuan. Sehingga apa yang dikonsepsikan bahwa ilmu pengetahuan bersifat ke Baratan dan mengandung dualisme terersebut bisa dilebur dengan ajaran tauhid dan beberapa normatif dalam agama Islam.

Jika melihat kedua alasan atau latar belakang perlunya Islamisasi menurut kedua tokoh ini, maka akan terlihat adanya kesamaan pemikiran yaitu bahwa peradaban yang dibawa oleh Barat adalah peradaban yang menjunjung tinggi nilai dikotomis. Dan nilai ini tentunya bertentangan dengan nilai yang ada dalam Islam yaitu tauhid. Hanya saja perbedaan kedua tokoh tersebut terlihat dalam segi latar belakang tentang perlunya diadakan sebuah Islamisasi. Al-Attas lebih melihat dan menganalisa permasalahan yang muncul di dunia Islam sekarang ini adalah pengaruh eksternal yang datang dari Barat sedangkan Al-Faruqi melihatnya dari masalah internal itu sendiri.

\section{Definisi Islamisasi Ilmu Pengetahuan}

Tentunya tidaklah mudah menafsirkan apa itu Islamisasi ilmu pengetahuan dan bagaimana formulasi Islamisasi ilmu pengetahuan ini di laksanakan. Definisi Islamisasi ilmu pengetahuan ini mengarahkan pada konsep ilmu pengetahuan dan Islam itu sendiri.

Islamisasi ilmu pengetahuan ini diterangkan secara jelas oleh al-Attas, yaitu Pembebasan manusia dari tradisi magis, mitologis, animistis, kulturnasional yang bertentangan dengan Islam dan dari belenggu paham sekuler terhadap pemikiran dan bahasa Juga pembebasan dari kontrol dorongan fisiknya yang cenderung sekuler dan tidak adil terhadap hakikat diri atau jiwanya, sebab manusia dalam wujud fisiknya cenderung lupa terhadap hakikat dirinya yang sebenarnya, dan berbuat tidak adil terhadapnya. Islamisasi adalah suatu proses menuju bentuk asalnya yang tidak sekuat proses evolusi dan devolusi.(Wan Mohd Nor Wan Daud, Filsafat dan Praktik Pendidikan Islam Syed M. Naquib alAttas, Hal. 341)

Berdasarkan pernyataan Al-Attas ini menunjukkan bahwa Islamisasi ilmu pengetahuan diharapkan bisa membebaskan kaum muslim yang bertentangan dengan Islam bahkan menjadikannya sekuler. Sehingga AlAttas berfikir bagaimana bisa mengembalikan kejayaan kaum muslim dan mengembalikan semuanya pada fitrahnya. Fitrahnya disini diartikan sebagai pemusatan ilmu pengetahuan yang berkembang ataupun yang sudah ada kembali pada peradaban Islam. Sebagaimana puncak kejayaan yang sudah pernah diraih oleh kaum muslim.

Menurut Al-Faruqi Islamisasi adalah usaha untuk mendefinisikan kembali, menyusun ulang data, 
memikirkan kembali argumen dan rasionalisasi yang berkaitan dengan data itu, menilai kembali kesimpulan dan tafsiran, memproyeksikan kembali tujuan-tujuan dan melakukan semua itu sedemikian rupa sehingga disiplindisiplin ini memperkaya wawasan Islam dan bermanfaat bagi cita-cita.

Secara umum, Islamisasi ilmu pengetahuan tersebut dimaksudkan untuk memberikan respon positif terhadap realitas ilmu pengetahuan modern yang sekularistik dalam model pengetahuan baru yang utuh dan integral tanpa pemisahan di antaranya. Proses pengintegralan antara ilmu pengetahuan yang berkembang didunia Barat dengan konsep Islam dan ilmu pengetahuan

Selain kedua tokoh di atas, ada beberapa pengembangan definisi dari Islamisasi ilmu pengetahuan tersebut. Sebagaimana yang diungkapkan oleh Osman Bakar, Islamisasi ilmu pengetahuan adalah sebuah program yang berupaya memecahkan masalahmasalah yang timbul karena perjumpaan antara Islam dengan sains modern sebelumnya.(Osman Bakar, Tauhid dan Sains, Hal. 233) Progam ini menekankan pada keselarasan antara Islam dan sains modern tentang sejauh mana ilmu pengetahuan dapat bermanfaat bagi umat Islam.

M. Zainuddin menyimpulkan bahwa Islamisasi pengetahuan pada dasarnya adalah upaya pembebasan pengetahuan dari asumsi-asumsi Barat terhadap realitas dan kemudian menggantikannya dengan pandangan Islam. (M. Zainuddin, Filsafat Ilmu: Persfektif Pemikian Islam, Hal. 160).

Dari pengertian Islamisasi pengetahuan diatas dapat disimpulkan bahwa Islamisasi dilakukan dalam upaya membangun kembali semangat umat Islam dalam mengembangkan ilmu pengetahuan melalui kebebasan penalaran intelektual dan kajian-kajian rasional, empirik dan filosofis dengan tetap merujuk kepada kandungan AlQuran dan Sunnah Nabi. Sehingga umat Islam akan bangkit dan maju menyusul ketinggalan dari umat lain, khususnya Barat.

\section{Proses Islamisasi Ilmu Pengetahuan}

Proses islamisasi ilmu pengetahuan ini akan bisa dilaksanakan ketika proses ilmu pengetahuan ini dilaksanakan dengan beberapa prinsip pokok yang ada pada agama Islam itu sendiri. Baik itu dalam prinsip pokok tauhid, syariah, maupun akhlak. Ketiga prinsip pokok tersebut haruslah menjadi pondasi dasar bagi ilmu pengetahuan yang ada.

Islamisasi ilmu pengetahuan ini bisa dilaksanakan dengan dua cara. Yakni yang pertama, dengan cara mengislamkan ilmu-ilmu pengetahuan yang ada maupun yang sedang berkembang. Yang kedua, dengan cara mengilmukan Islam. Dari kedua konsep Islamisasi ilmu pengetahuan ini dibahas oleh kedua tokoh besar dalam gagasan Islamisasi ilmu pengetahuan ini yakni Syed M.Naquib Al-Attas. Ismail Raji AlFaruqi.

Dalam pandangan Syed Naquib AlAttas proses Islamisasi ilmu ini bisa dilakukan dengan melalui dua cara. Yang pertama, ialah melakukan proses pemisahan elemen-elemen dan konsepkonsep kunci yang membentuk kebudayaan dan peradaban Barat. Dalam arti menjauhkan diri dari segala sesuatu yang menjadikan peluangpeluang terjadinya budaya yang menimbulkan suatu peradaban yang dihasilkan oleh orang-orang Barat. Misalnya, dalam budaya terdapat salah satu unsur budaya adalah bahasa. Bahasa disini memberi peluang terjadinya budaya yang menjadikan peradaban Barat. 
Mulai dari penggunaan bahasa hingga bagaimana memperlakukan bahasa tersebut. Contohnya dalam kajian sosiologi kita kenal dengan tokoh Emile Durkheim dengan beberapa teorinya dalam melihat masyarakat. Diantaranya mengenai konsep solidaritas. Konsep solidaritas ini seakan-akan menjadi gagasan awal yang disampaikan oleh Emile Durkheim. Namun perlu diketahui bahwa konsep solidaritas sudah ada sejak zaman terdahulu. Tepatnya pada zaman Ibnu Khaldun. Dimana Ibnu Khaldun sudah jauh mencetuskan dan menggagas konsep solidaritas yang disebut sebagai Ashobiyah ini dalam menjawab persoalan Negara. Menurut Al-Attas inilah yang harus dihilangkan. Sehingga tidak memunculkan klaim terhadap peradaban Barat.

Yang kedua, menurut Al-Attas adalah memasukan elemen-elemen Islam dan konsep-konsep kunci ke dalam setiap cabang ilmu pengetahuan masa kini yang relevan. Dalam arti konsep kedua ini Al-Attas menindaklanjuti konsepan yang pertama yakni dengan memasukkan nilai-nilai Islam dalam unsur-unsur ilmu pengetahuan tersebut.

Berbeda dengan pandangan Ismail

Raji Al-Faruqi. Dimana Al-Faruqi berpendapat bahwa Islamisasi ilmu pengetahuan ini dilakukan dengan cara menjadikan konsep tauhid sebagai pondasi dalam ilmu pengetahuan. Berikut merupakan esensi tauhid yang digambarkan Al-Faruqi dalam ilmu pengetahuan: (a) Tauhid / Keesaan Allah. Al-Faruqi ini berpandangan bahwa suatu yang esa atau mengandung unsur ketuhanan yang satu merupakan esensi dari segalanya. Bagaimana menciptakan suatu ilmu pengetahuan yang sifatnya bertauhid atau mengandung unsur ke-Esaan. Dalam menilai kebenaranpun bagaimana melakukan penilaian yang tidak menimbulkan dualisme kebenaran yakni kebenaran subjektif, objektif. Akan tetapi bagaimana nilai kebenaran tersebut bersifat tunggal. Yang mengerucut pada nilai-nilai ketauhidan; dan (b) Integrasi kebenaran Islam dan kebenaran ilmu pengetahuan. Menurut Al-Faruqi, kebenaran dalam Islam haruslah di integrasikan pada nilai-nilai kebenaran ilmu pengetahuan. Kebenaran ilmu pengetahuan disini kita kenal sebagai kebenaran yang melalui hukum-hukum logika yang dijadikan patokan sebagai tolak ukur standar kebenaran. Sumber kebenaran dalam ilmu pengetahuan yang terpusat dalam nilai-nilai rasionalitas dan nilai-nilai empiris yang lebih mengedepankan pengalaman sebagai ukuran kebenaran.

Sedangkan kebenaran dalam Islam bersumber pada wahyu dan kebenaran akal selagi tidak bertentangan dengan kaidah-kaidah dalam Islam dalam proses mengolahnya dengan akal manusia. Karena bagaimanapun, kepercayaan terhadap agama yang di topang oleh wahyu merupakan pemberian dari Allah dan akal juga merupakan pemberian dari Allah yang diciptakan untuk mencari kebenaran.

Islamisasi ilmu pengetahuan pandangan Al-Faruqi ini haruslah mengintegrasikan konsep kebenaran yang ada pada ilmu pengetahuan yang bersumber pada akal (rasionalitas) dan pengalaman (empiris) dengan konsep kebenaran Islam yang terletak pada keyakinan melalui wahyu dan ayat-ayat yang mempunyai sakralitas dalam agama tersebut.

\section{SIMPULAN}

Pada dasarnya paradigma dalam ilmu pengetahuan dan ilmu Islam adalah menemui kesamaan-kesamaan. Dimana dalam sejarah yang ada bahwa 
ilmu pengetahuan ini berawal dari sebuah pemikiran-pemikiran cendekiawan muslim yang menghasilkan suatu peradaban pengetahuan dalam Islam itu sendiri. Namun dengan adanya perkembangan zaman tersebut maka ilmu pengetahuanpun berkembang begitu pesat tanpa adanya kontrol dari agama Islam sendiri yang mengakibatkan adanya ilmu pengetahuan yang tidak beretika.

Sehingga seiring dengan berputarnya waktu menimbulkan stigma mengenai adanya ilmu surga dengan ilmu yang berlumuran dosa yakni ilmu pengetahuan yang liberal. Dengan begitu seakan-akan terjadi pembedaan dari kedua ilmu tersebut. Dari fenomena tersebut muncullah sebuah cendekiawan muslim yang mengkritisi mengenai fenomena tersebut dengan memunculkan gagasan Islamisasi pengetahuan.

Ilmu pengetahuan lebih memusatkan pada nilai-nilai kebenaran yang sifatnya empiris. Dimana nilai-nilai empiris ini menjadi pondasi awal dalam ilmu pengetahuan menilai kebenaran. Kebenaran empiris inilah yang menjadi patokan dalam ilmu pengetahuan. Sedangkan kebenaran ilmu pengetahuan ini ironis dengan kebenaran yang ada di agama. Dimana nilai kebenaran yang ada di agama ini selain mengarahkan pada nilai kebenaran empiris tapi juga menilai kebenaran dari nilai dogma atau kepercayaan terhadap sesesuatu yang sifatnya terkadang sangat irasional.

Nilai kebenaran inilah yang seakan akan menjadi sebuah pembatas atau pembeda antara ilmu pengetahuan dan nilai-nilai Islam inilah yang menjadikannya sebagai pembeda dalam suatu ruang. Dari pembedaan inilah yang menimbulkan beberapa tokoh Islam mencoba untuk berusaha mengintegrasikan nilai-nilai yang ada di
Islam dengan kaidah-kaidah ilmu pengetahuan.

Islamisasi pengetahuan ini juga diawali dengan adanya keresahan dan kekecewaan pada kaum muslim dalam melihat fenomena betapa pesatnya perkembangan ilmu pengetahuan yang tidak didasari sebuah nilai-nilai agama khususnya agama Islam. Dalam hal ini agama Islam. Sehingga perkembangan ilmu pengetahuanpun bisa menjadikan seseorang menjadi sekuler. Dengan terjadinya sekuler ini kedua tokoh tersebut ingin mengembalikan ilmu pengetahuan pada nilai-nilai agama.

Nilai-nilai agama disini diartikan suatu yang fundamental dalam perkembangan ilmu pengetahuan apapun. Nilai-nilai agama dijadikan sebagai pondasi dasar dalam ilmu pengetahuan. Diantara pemikiran kedua tokoh tersebut mempunyai tawaran yang berbeda dalam konsep Islamisasi ilmu pengetahuan.

Syed M.Naquib Al-Attas menawarkan dua opsi dalam melakukan Islamisasi ilmu pengetahuan. Pertama, dengan melakukan pemisahan konsep-konsep kunci yang membentuk kebudayaan dan peradaban Barat. Kedua, dengan memasukan konsep kunci Islam ke dalam setiap cabang ilmu pengetahuan masa kini yang relevan.

Dalam hal ini Ismail Raji Al-Faruqi juga menawarkan dua Konsep dalam melakukan Islamisasi ilmu pengetahuan. Yakni tauhid, integrasi kebenaran Islam dan ilmu pengetahuan, dan ayatisasi atau pemberian ayat-ayat terhadap ilmu pengetahuan.

Dari kedua konsep yang ditawarkan oleh para tokoh tersebut dilatarbelakangi oleh pemikiran yang bebeda pula. Dimana Syed Naquib AlAttas melihat situasi kondisi umat muslim dengan melihat kondisi external umat muslim itu sendiri yakni proses degradasi dan kemunduran- 
kemunduran yang dialami oleh kaum muslim yang salah satunya disebabkan oleh orang-orang Barat dan budaya Barat seperti halnya westernisasi atau hidup kebarat-baratan dan sekulerisasi atau pembedaan antara kehidupan didunia dengan agama.

Sedangkan Ismail Raji Al-Faruqi Lebih melihat pada faktor internal kaum muslim itu sendiri. Dimana peradaban dan kejayaan umat muslim kini perlu dipertanyakan sehingga bagaimana bisa mencapai peradaban dan kejayaan kaum muslim yakni dengan cara Islamisasi ilmu pengetahuan.

\section{DAFTAR RUJUKAN}

Bakar, Osman. 1994. Tauhid dan Sains. Bandung: Pustaka Hidayah.

Burhanuddin. Salam. 1997. Logika Materil, Filsapat Ilmu Pengetahuan. Jakarta: Reneka Cipta.

Daud, Wan Mohd Nor Wan. penerjemah Hamid Fahmi dkk, Filsafat dan Praktik Pendidikan Islam Syed M. Naquib Al-Attas, Bandung: Mizan, 2003.

Sumantri, Jujun. 2009. Filsafat Ilmu Sebuah Pengantar Popular. Jakarta : Pustaka Sinar Harapan.

Zainuddin, Muhammad. 2003. Filsafat Ilmu: Persfektif Pemikian Islam. Malang: Bayu Media. 